\title{
Competitiveness Analysis of Chinese Service Trade
}

\author{
Jing $\mathrm{Ma}^{1, \mathrm{a}}$ \\ ${ }^{1}$ Xijing University, Xi'an,710123 \\ a email532824757@qq.com
}

Keywords: Service Trade, Competitiveness Analysis

\begin{abstract}
With the rapid development of international trade in services and its special role in the national economy as a whole to promote the efficiency and improve the quality of trade in services has become a worldwide research frontier subject. This article is dedicated to the research and countermeasures of China's service trade international competitiveness.
\end{abstract}

\section{Introduction}

In the 1980s, the emergence of a second upsurge of trade in services research, research in this stage is mainly concentrated in the traditional international trade theory to trade in goods as the core of whether the same applies to trade in services. Until the mid-1980s, researchers have confirmed that the comparative advantage theory applies to trade in services, followed by international trade theory began to try to use standard or amendment of the decision to explore the issue of trade in services. Its contents include normative analysis and empirical analysis two, the former is the use of traditional international trade theory to explore the reasons for the occurrence of trade in services, direction and interest gains and losses; the latter through the study of the realities of international trade in services data and analysis of international services developments and changes in trade patterns, and traditional international trade theory for verification.

\section{Basic Concept of Services Trade}

GATS definition of trade in services under the services trade, including cross-border supply, consumption abroad, commercial presence and movement of natural persons in four areas. Cross-border delivery. It refers to the service provider to provide services in the territory of the consumer within the territory of a member of another member. For example, in the United States attorney to provide legal advisory services to clients in the UK. This service delivery with particular emphasis on the buyer and seller in geographical boundaries, across borders and boundaries but the service itself, the requirements of scale, management and technology service providers have service in general. Generally refers to modern communication technology-based services, such as consulting services, satellite television services, network services. Such as management, located in the home country does not move, but can provide services through information and communication technologies to strengthen overseas production factors. Indeed/logistics curtain grip, winning a thousand miles o. Consumption abroad. It refers to the service provider to provide services within the territory of a member from another consumer member. The main feature of this approach is that the service provided by the service consumer transit movement to achieve, the most typical is the international tourism, mainly dependent on labor resources, natural resources, cultural resources and comparative advantages. Such services also include education and training, health care, technology identification. Commercial presence. It refers to a member of the service provider to set up businesses or professional bodies in the territory of another Member, provide services to consumers within the territory of the latter. This way both within the territory of a member of the constitution, acquisition or maintenance of a legal entity, it can be to create and maintain a branch or representative office. For example, a member of the bank or insurance company to open branches in the territory of another Member or branches, providing financial and insurance services. Such trade has two characteristics: First, service providers and consumers in the territory of the same member; the second is the service provider to the territory of the country where the consumer has taken the 
way to set up commercial organizations or professional bodies. Such trade generally involves market access and direct investments. Established in overseas financial institutions, technical advice centers, accounting firms, research centers, service stations and other services are the way of trade in services such common forms. Movement of natural persons. Such services with a consumer by moving the opposite way, mainly refers to the transit service provider moves to provide services in consumers territory formed by trade. For example, a husband is a lawyer A country, he came to country B, they do not set up their own firm, and direct provision of legal advisory services. One such service is the most common and oldest way is labor export.

\section{Development and Influence of Chinese Service Trade}

In recent years, the development of global trade in goods and trade in services to keep pace with an average annual growth of about 6\%, the share of trade in services in international trade has remained at around 20\%. According to World Trade Organization (wOT) statistics, in 2004, under international and domestic strong economic growth, the rapid growth of domestic trade in goods and foreign direct investment in China rose steadily, driven by our foreign service trade has maintained a good momentum of development, last year international trade in services balance to the total size of $\$ 134.6$ billion, up 32\%, respectively, gross domestic product (GDP) and foreign trade (including goods and services) of $8 \%$ and $10 \%$. Among them, the movie audio and video, advertising, consulting, transportation, travel, computer information services revenue surged scale, an increase of more than 35\%. International tourism is still the largest item of trade in services, the size of the total $\$ 44.9$ billion revenue acounts for 33\% of the size of the entire balance of trade in services increased by .14 percentage points. Foreign trade in services trade in services revenue growth slightly higher than expenditures, revenues \$ 62.4 billion, spending \$ 72.2 billion, up 34\% and 30\%. Services trade deficit $\$ 9.8$ billion, expanding by 13\%, but the magnitude of the expansion of the deficit has declined. According to the WTO report of 2004, global trade in services exports of \$ 21 trillion, up 16 percent over last year, China sort in world trade in services in the same 2003, ranking No. 9 export, import ranks No. 8 bit.

\section{The Measures to Improve the International Competitiveness of China's Service Trade}

Global economic integration under the China Service Trade International Competitiveness is in fact, China's service industry in the international market and domestic market competitiveness. On the one hand, our ability to service products and services to international markets and gain a higher market share; on the other hand, in the domestic market after the opening of the WTO, China's service industry can withstand the impact of foreign products and services, survival and development in the fierce competition. No matter which improves competitiveness in the market, its root cause are their own development and growth of the service sector. Objectively speaking, the development of China's service trade has with the external pressure and internal motivation. Subjectively speaking, however, we also need to have clear ideas and practical strategies to find a feasible way to improve the competitiveness of China's service trade. In accordance with the development of trade theory, a country at different stages of their development, and promote the momentum of growth is different. Since developing countries lack the financial and technical plaque, dynamic trade growth has mainly come from primary comparative advantage trade development. Here's primary comparative advantage refers to the natural endowments such as abundant natural resources or labor resources. However, due to the technical content of these products is low, the production level is not high, the product is very limited space to expand trade growth to a certain period will face power conversion requirements. In trade growth into the second stage, the comparative advantage rises from natural endowment to technology, management and marketing network acquired comprehensive endowment. This comparative advantage comes from the dynamic effects of high-class trade sector development. In this effect, the trade not only brings optimum allocation of resources, but also bring trade sector through the production of innovative technology spillover and learning by doing, so that comparative advantage rises to acquired 
endowments stage. However, with the accumulation of acquired endowments, how macro-control advantages of resources to optimize the combination of long-term dynamic is the key to competitive advantage. From beginner to advanced comparative advantage comparative advantage, to a competitive advantage, we must follow the principle of such a power converter in order to find ways to improve competitiveness.

Development of services using the theory of comparative advantage. On the basis of comparative advantage, will feature elements of its own resource endowment can be used with the combine to create a comparative advantage in the production of commodities-related services. China is a vast land, historic country's own natural endowments quite rich. To these natural endowments into comprehensive endowment, so that the primary comparative advantage based on natural endowments for the development of advanced integrated comparative advantage based on endowments, depends on two factors: First, the existing natural endowments full understanding. On the current situation, we can create a primary comparative advantage of China's service trade natural endowments including labor resources, natural geographical environment and cultural resources.

Create new competitive advantages in the macro, meso and micro levels. Porter's Competitive Advantage of Nations fully emphasized the importance of government in determining the state's industrial competitiveness, noting that the four stages in the development of competitive advantages are inseparable from the role of government. State is the chief representative of a country's trade in services, there is no government to improve the development of trade and services at competitive macro-coordination and control of services can never be guaranteed. To this end, the following aspects should improve the international competitiveness of China's trade in services. Proper government to protect their national service industry will enhance the international competitiveness of China's trade in services. For convenience, we may wish to the financial industry, for example, to protect the financial markets with a strategy to promote export trade model to be discussed. Assumed:. A domestic financial services market is oligopolistic market share seller. In other words, manufacturers can develop different prices in different markets. These two assumptions for Chinese financial industry have certain rationality. From the current market opening of China's financial services practice, China by geographical segment, the business segment (segment RMB and foreign currency business, etc.), customer segmentation (such as foreign companies and domestic companies, groups and individuals, financial companies and non-financial companies) and other methods to the entire financial services market is divided into many small segments of the market, but also in the different markets, oligopoly phenomenon does exist, China's four state-owned bank assets accounted for 70 of the total assets of the banking system \%the above. Moreover, given the large Chinese state-owned commercial banks operating outlets, as long as strengthen management to improve operations, there are economies of scale possible.

Services trade infrastructure of a country is to improve the international competitiveness of trade in services important determinant, which seriously affect the way the modern service trade, size and quality, it is also about the development of service trade international competitiveness. For example, in our maritime services, though they have a comparative advantage geographical environment and labor resources, but the average tonnage of small vessels, low level of technology, can not be found moored in the port of the global PSC network; port handling equipment is very old, low handling efficiency, can not meet the needs of large-scale handling. Lagging infrastructure severely hampered our shipping services comparative advantages. In addition, roads, railways, bridges, computer and communications systems and other facilities are the basis for the development of the service industry. In particular, information infrastructure, cheap and effective electronic communication systems, the Internet and the information superhighway many of the original non-tradable services can become a trade. In developed countries, almost all types of information technology facilities and services is also essential to enhance the competitiveness of the internet. From the financial, insurance to retail, tourism management, and from air transport to road, rail and sea transport, information technology industries regarded as an important means of marketing 
facilities management. IT services changed the basis of competition, reduce management costs and transaction costs. For the development of electronic commerce services provided by the network to expand business activities more convenient channel, greatly contributed to the international competitiveness of a country's trade in services $=24]$. human capital. Human capital formation of trade in services has obvious competitive advantage early. From a macro perspective, the overall level of a country's education development, and related educational structure to adapt to the new economic development of the education system, determines the growth of talent emerging service environment, determines the availability of high-quality professionals related businesses, which determines the size of a country's service sector competitiveness. Services Western countries have a competitive advantage Most services offer high-quality, high-tech features of knowledge workers. During the entire structure of international trade in services from the transition to a knowledge and technology-intensive, labor-intensive, we should increase the human capital and R \& D investment, will help improve the value-added service offerings to help service trade in static comparative advantage formed on the basis of competitive advantage.

\section{Conclusion}

Mature international trade theory is based on trade in goods for the research center. For trade in services, it has not yet been an independent, systematic theoretical framework. In order to enhance our international competitiveness of trade in services as a whole, we must on the one hand, from the current development level of development of China's service trade and services start, give full play to comparative advantages, promote the services sector upgrading of industrial structure and industry structure optimization; on the other hand, on the use of the competitive advantage to a senior primary comparative advantage comparative advantage a competitive advantage to trade power conversion path, combined with external conditions and internal motivation, from the macro, meso and micro levels, that government, industry and three companies to seek to improve the international competitiveness of trade in services action Strategies.

\section{References}

[1] Ochel. W, The international competitiveness of business service firm: The case of Germany [J], The service Industries Journal, 2002, 22 (2): 1-16.

[2] Brigitte. R The German service gap or reorganizing the manufacturing services puzzle [J], Metro economic, 2007, 8 (3): 457-478.

[3] Francois \& Woerz, Producer services manufacturing linkages, and trade [J], Tinbergen Institute Discussion Paper, 2007, No.07-045/25.Michael Porter, The Competitive Advantage of Nations [M] .Harvard Business School Pred, 1990: 2.

[4] Deardorff.A, Testing Trade the oriesand Predicting Trade Flows, Handbook of International Economies 1984, Vol.1, P.467 - 517.

[5] Diek. R. and Dieke, H.5 Patterns of Trade in Knowledge, International Economic Development and Resource Transfer, 1979. 